\title{
BŪSIMŲJŲ KŪNO KULTŪROS MOKYTOJŲ PROFESINE் SOCIALIZACIJA: GIMTOSIOS KALBOS GEBËJIMŲ VERTINIMAS PEDAGOGINĖS KOMUNIKACIJOS POŽIŪRIU
}

\author{
Laimutė Kardelienė ${ }^{1}$, Kęstutis Kardelis ${ }^{1}$, Vilija Bitė Fominienė ${ }^{1}$, Tomas Bardauskas ${ }^{2}$ \\ Lietuvos kūno kultūros akademija ${ }^{1}$, Kauno medicinos universitetas ${ }^{2}$, Kaunas, Lietuva
}

\begin{abstract}
Laimutė Kardelienė. Socialinių mokslų (edukologijos) daktarè. Lietuvos kūno kultūros akademijos Sveikatos ir fizinio aktyvumo katedros profesorè. Mokslinių tyrimų kryptys — profesinis identitetas, mokytojų profesinė kompetencija, ugdomoji sąveika, fizinis aktyvumas ir sveikata.
\end{abstract}

\begin{abstract}
SANTRAUKA
Straipsnyje gilinamasi i būsimuju kūno kultūros mokytoju gimtosios kalbos gebèjimu vertinima pedagoginès komunikacijos požiūriu. Iškeliama gimtosios kalbos svarba būsimuju mokytoju profesionalizacijai aukštojoje universitetineje mokykloje. Mokslininkai gilinasi ̨ būsimuju kūno kultūros mokytoju profesinès kalbos vartojimo aktualijas, tačiau dar stokojama tyrimu apie šiu specialistu pedagoginę komunikavimo kompetencija pedagoginejje veikloje, ypač apie šios kompetencijos lingvistini komponenta, kuris retai tampa tyrimu objektu. Lingvistinis komponentas - gimtosios kalbos gebejjimai, kuriuos lemia asmenybès žinios, mokejjimai ir vertybinès nuostatos dèl gimtosios kalbos vartojimo ugdant mokiniu kūno kultūrq.

Organizuotas tyrimas taikant klausimyna, kuris leido atskleisti, kaip būsimieji kūno kultūros mokytojai vertina gimtosios kalbos gebejimus profesinès socializacijos srityje. Tiriamaja imti kohortinio tipo longitudinio tyrimo metu sudare 149 LKKA studentai, parinkti iš Sporto edukologijos fakulteto antro $(n=89)$ ir ketvirto $(n=60)$ kursu. Interpretuojant būsimuju kūno kultūros mokytoju gimtosios kalbos svarbos vertinimus ugdant mokiniu kūno kultūrq profesionalizacijos požiūriu teigtina, kad studijuojant gimtoji kalba dažniau traktuojama kaip instrumentinè, rečiau — kaip terminalinè vertybe.

Apibendrinant tyrimo duomenis manytina, kad būsimieji specialistai gimtaja kalba pedagoginès komunikacijos požiūriu vertina pragmatiškai. Tyrimo rezultatai leidžia būsimuju pedagogu gimtosios (lietuviu) kalbos vertinima ugdant mokiniu kūno kultūra ìvardyti kaip kintamaji gilinantis i ju profesionaluma, ypač i profesinès veiklos veiksminguma.
\end{abstract}

Raktažodžiai: profesinè socializacija, gimtosios kalbos gebëjimai, pedagoginè komunikacija.

\section{IVADAS}

Š iuolaikinè visuomenè - tai spektaklio ir reginio visuomenè, vartotojų visuomenè arba postmodernistinè visuomenè. Ji kuria fragmentuotą individo tapatybę, besiremiančią vaizdinių ir įvaizdžių žaismu. Šis procesas skatina gilintis ị esamą ir prognozuoti būsimą sociokultūrinio gyvenimo situacija. Tyrimai rodo, kad akademinis jaunimas, kuri galima būtų ịvardyti kaip jaunimo elitą, patiria daugybę socialinių susidūrimų (Unalan et al., 2008), todèl žvilgsnis krypsta i jaunimo tapatumo ir savasties konstravimo ypatumus globalioje visuomeneje. Globalizacija - tai pasaulinių santykiu ir tarpusavio priklausomybès stiprejjimas. Europos komisijos, Europos tarybos dokumentuose akcentuojama Europos šaliu ir ju kultūrų išsaugojimo svarba (Teaching and Learning: Towards the Learning Society, 1995), nes dèl anglų kalbos itakos kinta vietinių kalbu sistemos, žodynas, tarimas, ortografija, gramatika (Уорд, 2003; Girčienè, 2005). 
Lietuvoje aktualizuojama mokytojo komunikacinè kompetencija gimtaja (lietuviu) kalba: aptariamos būsimujų mokytoju profesinès kalbos vartojimo aktualijos (Župerka, 1997), pateikiamos pamokos apie kalbos stiliaus ypatybes (Kardelienè, Kardelis, 2006), nurodomos bendrinès kalbos normų ir kultūros normų sąsajos (Pupkis, 2005). Stokojama tyrimų apie būsimuju kūno kultūros mokytoju gimtosios kalbos vartojimo vertinima profesinèje veikloje. Kadangi vaikų sveikatą stiprinančio fizinio aktyvumo nuostatas gali ugdyti toks mokytojas, kuris geba paprastai ir itaigiai aiškinti mokiniams keliamus uždavinius ir reikalavimus, tai tokių pat gebèjimų reikia specialistui, siekiančiam, kad kūno kultūros pamokose mokiniai formuotųsi visuomeniškai ir tautiškai kryptingam nariui būtinas savybes, tobulintų bendravimo igūdžius.

Išsakytieji teiginiai skatina gilintis ị būsimuju kūno kultūros specialistų pedagoginę komunikacinę kompetenciją, ypač i jos pagrindą — gimtosios kalbos gebejimus, kuriuos lemia ne tik asmenybès žinios, mokèjimai, bet ir vertybinès nuostatos dèl gimtosios kalbos vartojimo ugdant mokiniu kūno kultūrą. Mažai tyrimu, tiesiogiai analizuojančiu ši fenomeną (Kardelienè, Gudzinevičiūte, Mykolaitienė, 2005; Чучалина и др., 2005), o daugiau aprašančių būsimujuc ir pradedančiujų kūno kultūros mokytojų kompetencijų turini, kuriame pateikiami profesinès karjeros modeliai ar profesinès socialiCapel et al., 2004), pedagoginès sąveikos ugdant mokinių kūno kultūrą bruožai (Ryan et al., 2003; Malinauskas, 2004; Vilkas, Raškauskienè, 2005; Fominienè, 2007).

Aprašytoji situacija paskatino atlikti tyrimą, kuriuo keltas probleminis klausimas: kas būdinga tokiai būsimujuc kūno kultūros mokytojų profesinès socializacijos apraiškai kaip gimtosios kalbos gebejjimų vertinimas pedagoginès komunikacijos požiūriu. zacijos etapai (Curtner-Smith, 2001; Chen, 2003;

Tikètina, kad studijuojant būsimujų mokytoju gimtosios kalbos gebejjimų vertinimas pedagoginès komunikacijos požiūriu kinta, o pokyčiuose ryškèja pragmatiškumas.

Tyrimo tikslas - atskleisti tokią būsimujuc kūno kultūros mokytojų profesinès socializacijos apraišką kaip gimtosios kalbos gebejjimų vertinimas pedagoginès komunikacijos požiūriu.

\section{TYRIMO METODIKA}

Tiriamieji. Tiriamają imti sudare 149 antro ir ketvirto kurso LKKA Sporto edukologijos fakulteto studentai. Apklausti 89 (47 vaikinai ir 42 merginos) antro kurso ir 60 (28 vaikinai ir 32 merginos) ketvirto kurso studentu.

Tyrimo metodas. Gimtosios kalbos gebejjimų vertinimas pedagoginès komunikacijos požiūriu tirtas taikant apklausos raštu metodą (Kardelienè, Kardelis, 2006). Klausimyno turini sudare teiginiu skale ir atskiri klausimai tokiais gimtosios (lietuviu) kalbos vartojimo aspektais: gimtosios kalbos pasiekimai bendrojo lavinimo mokykloje, gimtosios kalbos tobulinimo būdai paskutiniais metais, Kalbos komisijos parengto Didžiujų kalbos klaidu sąrašo išmanymo lygmuo, namų bibliotekos komplektavimas gimtosios kalbos tobulinimo klausimais. Be to, tiriant pedagoginès komunikacijos vertinimą ugdant mokinių kūno kultūrą teirautasi, kaip būsimieji kūno kultūros mokytojai reaguoja i jų kalbėjimo taisymus.

Tiriamujų gimtosios kalbos gebejjimų vertinimas pedagoginės komunikacijos požiūriu, kaip priklausomas tyrimo objekto kintamasis, atskleistas taikant 28 teiginiu skalę. Skalès teiginiai formuluoti vadovaujantis pedagoginei komunikacijai aktualiais lingvistiniais specialisto gebejjimais ir itraukiant teiginius, kuriuos reflektuodami būsimieji mokytojai atskleidžia vertybines nuostatas dèl gimtosios kalbos vartojimo ugdant mokiniu kūno kultūrą.

Pav. Gimtosios kalbos gebėjimų gilinimo kaita

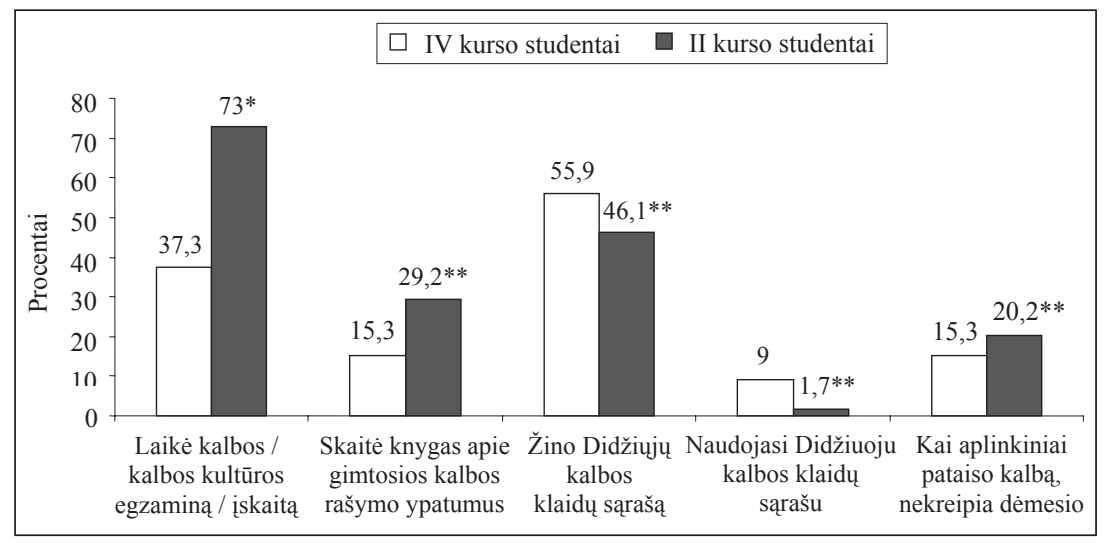

Pastaba. ${ }^{*}-\mathrm{p}<0,05 ;{ }^{* *}-<0,001$. 
Skalę sudarè teiginiai apie gimtosios kalbos gebejjimų svarbą ugdant mokinių kūno kultūrą. Tiriamieji, vertindami teiginius, atskleidžia profesinès socializacijos vyksmą, nes šios skalès teiginiai surinkti kūno kultūros mokytojams tobulinant kompetenciją dalykiniuose seminaruose. Skalès teiginiu atsakymai vertinti penkių balų Likerto skalèje nuo visiškai pritariu iki visiškai nepritariu. Vertinant gimtosios kalbos gebejjimu pokyčius profesinès socializacijos srityje, atsakymų i skalès teiginius variantai visiškai pritariu ir pritariu sujungti i vieną (žr. lent.).

Procedūros. Tyrejjas informavo studentus apie tyrimo tikslą ir paaiškino, kaip pildyti klausimyną. Per pratybas studentai užpilde klausimyną ir atidavè ji tyrejjui. Ši tyrimo procedūra leido tyrejui surinkti visus išdalytus klausimynus. Pažymètina, kad konkrečiose pratybose visi buvę studentai pilde klausimynus, o ị jiems iškilusius klausimus atsake tyrejas. Be to, jis akcentavo tyrimo anonimiškumą ir pabrèžè, kad dalyvavimas tyrime yra savanoriškas. Tai reiškia, kad galima pasitraukti iš tyrimo ir nebaigus pildyti klausimyno.

Statistinė analizè. Tyrimo duomenims skaičiuoti taikyta SPSS for Windows 14 programa. Tirtų rodiklių statistiniai ryšiai analizuoti naudojant $\chi^{2}$ ir $Z$ kriterijus.

\section{REZULTATAI}

Tyrimo duomenys apie studentu gimtosios kalbos gebejimus II ir IV kurse rodo, kad ivyko statistiškai reikšmingi jų plètotès pokyčiai (žr. pav.).

Paveikslo duomenys rodo, kad mažiau studentu IV kurse laikè gimtosios kalbos egzaminą ar kalbos kultūros įskaitą (tai būdinga ir vaikinams, ir merginoms). Pokyčiai atsakant i ši klausimą ryškesni tarp merginu: $83,3 \%$ antrame kurse, ketvirtame $35,5 \%(\mathrm{p}<0,001)$. Iš vaikinų atsakymų matyti, kad antrame kurse $63,8 \%$ jų laiké gimtosios kalbos egzaminą ar kalbos kultūros iskaita, o ketvirtame tai nurodė 39,3\% tirtų jaunuolių ( $<<0,05)$. Ketvirtame kurse studentai, vaikinai ir merginos, rečiau konsultavosi su kalbininkais, lietuvių kalbos mokytojais (antrame kurse vaikinai - 31,9\%, ketvirtame $7,1 \%(\mathrm{p}<0,05)$; antrame kurse merginos - 35,7\%, ketvirtame - 12,9\% $(\mathrm{p}<0,05))$. Be to, ketvirtame kurse studentai mažiau laiko skyrẻ knygoms apie gimtosios kalbos rašybos ypatumus.

Būsimujų kūno kultūros mokytojų profesinè socializacija aukštojoje mokykloje vertinant gimtosios kalbos gebejjimų svarbą rodo, kad studentai tiriamą reiškini traktuoja kaip instrumentinę vertybę, leidžiančią jiems gerai funkcionuoti ugdantis profesinę kompetenciją. Pavyzdžiui, iš tiriamuju atsakymu matyti tendencija, kad ketvirtame kurse jie dažniau nurode žiną Kalbos komisijos parengtą Didžiuju kalbos klaidų sąrašą ir juo naudojosi. Kita vertus, ketvirtame kurse studentai rečiau atsižvelgia į aplinkinių pastabas dèl jų kalbos taisyklingumo. Be to, tyrimo rezultatai apie gimtosios kalbos tobulinimui skirtu leidinių (Tarptautiniu žodžiu žodyną, Dabartinès lietuvių kalbos žodyną, lietuviu kalbos rašybos ir skyrybos vadovèlius, žinynus ir kt.) turèjimą savo namų bibliotekoje rodo nedidelius pokyčius.

Tyrimo duomenys apie tokią būsimujų kūno kultūros mokytojų profesinès socializacijos apraišką kaip gimtosios kalbos gebejjimų vertinimas pedagoginès komunikacijos požiūriu pateikti

\begin{tabular}{|c|c|c|c|}
\hline \multirow{2}{*}{ Teiginiai } & \multicolumn{2}{|c|}{ Apklaustųjų procentas } & \multirow{2}{*}{$\begin{array}{l}\text { Lentelè. Profesinèse so- } \\
\text { cializacijos pokyčiai ver- } \\
\text { tinant gimtosios kalbos } \\
\text { gebėjimus }(\%)\end{array}$} \\
\hline & II kursas & IV kursas & \\
\hline $\begin{array}{l}\text { Prie sporto salès turi būti kalbos kultūros stendas (,Taisyklingai } \\
\text { kalbėkime“ ar pan.) }\end{array}$ & 16,1 & $25,4^{*}$ & \\
\hline Esame lietuviai ir privalome rūpintis savo kalba & 97,8 & 93,2 & \\
\hline $\begin{array}{l}\text { Kūno kultūros specialistams būtina kalbos kultūros disciplina aukštojoje } \\
\text { mokykloje }\end{array}$ & 62,5 & $81,4 * *$ & \\
\hline $\begin{array}{l}\text { Pedagogo kvalifikacijai svarbi kalbos kultūros įskaita (mokytojų } \\
\text { atestacijos) }\end{array}$ & 51,1 & $74,6 * *$ & \\
\hline Taisyti netaisyklingą vaikų kalbą — ne kūno kultūros mokytojo tikslas & 41,6 & 54,2 & \\
\hline Vaikų kalbos taisyklingumas — lietuvių kalbos mokytojų reikalas & 21,3 & $42,4 * *$ & \\
\hline Kaip kalba treneris, taip kalba ir jo aukletiniai & 61,6 & 69,5 & \\
\hline Kalbininkai dažnai kelia perdėtus, neapgalvotus reikalavimus & 73,0 & 57,6 & Pastaba. * - rezultatų \\
\hline Kiekvienam angliškam terminui reikia ieškoti lietuviško pakaitalo & 44,9 & 39,0 & tarp kursu $(p<0,05)$ \\
\hline Vaikai geriau supranta mokytoją, kai šis kalba jų kalba & 69,7 & 64,4 & \\
\hline
\end{tabular}


lentelèje (žr. lent.). Lentelèje surašyti teiginiai, kuriuos studentai antrame ir ketvirtame kurse vertino skirtingai.

Lentelejje pateikti duomenys leidžia teigti, kad studijuodami būsimieji kūno kultūros mokytojai palankiau vertina tokią profesinès socializacijos apraišką kaip gimtosios kalbos gebejjimus. Kita vertus, padaugèjo manančių, kad vaikų kalbos taisyklingumu turètų rūpintis kitų specialybių mokytojai. Gilinantis i tyrimo duomenis teigtina, kad studijos gali paveikti būsimujų specialistu gimtosios kalbos gebejimų vertinimą pedagoginès komunikacijos požiūriu. Taip samprotauti leidžia tyrimo metu nustatytas ir didejjantis skaičius tokių studentų, kurie vis dažniau pripažista, kad trenerio ir kūno kultūros mokytojo kalba ugdo vaikų kalbą.

\section{REZULTATUQ APTARIMAS}

Lietuvoje išgyvenamos sociokultūrinès trasformacijos dèl integracijos i europinius ir globalius veiklos kontekstus, todèl visuomenè sunerimusi dèl lietuvių (gimtosios) kalbos vartojimo. Atsiranda ideologinè atskirtis tarp pasisakančiuju už kalbų jungimąsi ir besirūpinančių, kad tautinių mažumų kalbos nebūtų išstumtos ì privačią vartojimo erdvę. Debatai šia tema naudingi, nes atkreipia akademinès bendruomenès dèmesi $i$ dvikalbystès reiškini. Pavyzdžiui, anglų kalbos studijų reikšmę specialisto kompetencijai gilinti, nes šios kalbos išmanymas leidžia susipažinti su kitų šalių tos pačios srities profesionalų veikla, praturtina kultūrinę patirtí. Tokie nuomonių skirtumai vertingi, nes skatina atsakyti į klausima kokị dèmesi dera skirti būsimajam specialistui lietuvių kalbos, kaip gimtosios, ugdymuisi. Ypač šis klausimas aktualus rengiant būsimaji kūno kultūros mokytoją, nes profesinejje veikloje labiau vertinamas jo dalykinès kompetencijos funkcinis komponentas (sporto šaku technikos ir taktikos įvaldymas), mažiau — komunikavimo gebejjimai (Kardelienè, Kardelis, 2006; Hardman, 2008). Kadangi i kūno kultūros pamoką žvelgtina kaip i vaiko socialinès ir emocinès raidos laboratoriją, tai tik kalbos etikos ir estetikos klausimus išmanantis mokytojas gali realizuoti šioje laboratorijoje sprendžiamus uždavinius. Tačiau kiekviena specialistu grupe sociologu ivvardijama kaip grupè, turinti savają subkultūrą. Kitaip tariant, tai yra diskurso bendruomené, kurią sudaro tarpusavio priklausomybe susieti asmenys su jiems būdingais kalbos vartojimo tikslais ir keitimosi informacija metodais (Trayner, 2000).
Diskurso bendruomenès samprata grindžiama diskursu, t. y. kalbos organizacija metasintaksiniu lygmeniu ir individualiais kalbėsenos pokyčiais, kuriuos lemia bendros reikšmès paieška sąveikos vyksme. Taigi ir profesinè bendruomenè yra diskurso bendruomenè, kurią atpažistame iš tos srities specialistams būdingų kalbos elementų. Bendravimo, ypač kalbos raiškos priemonių, ypatumai rodo ir profesinę kompetencija, ir priklausomybę tam tikrai socialinei grupei. Profesionalu gimtosios kalbos (lietuvių) vartojimą šiuolaikiniame pasaulyje veikia bendrieji visuomenès procesai: anglų, kaip vienintelès pasaulinès kalbos, ịsigalejjimas, valstybès bei kalbos ugdymo institucijų, taigi ir Lietuvos kūno kultūros akademijos, dokumentai apie gimtosios kalbos ugdymo strategiją rengiant kūno kultūros mokytojus. Tyrimo rezultatai iliustruoja šių dokumentu igyvendinimą. Pirmiausia IV kurse studentai palankiau nei II kurse vertina gimtosios kalbos gebejjimus ugdant mokinių kūno kultūrą. Antra, ketvirtame kurse būsimieji specialistai dažniau pritaria teiginiui, kad kūno kultūros mokytojo ir trenerio kalba daro itaką vaikų kalbai. Tyrimo rezultatai atskleidè ir tradicini supratima apie gimtosios kalbos vertę kūno kultūros veikloje. Ketvirtame kurse dažniau nei antrame būsimieji specialistai mano, kad mokinių kalbos taisyklingumu turi rūpintis kiti mokytojai.

Aprašytuosius gimtosios kalbos gebejjimų vertinimo pedagoginès komunikacijos požiūriu ypatumus galima apibūdinti kaip pragmatinius. Kitaip tariant, profesinès socializacijos raida studijuojant formuoja profesinį identiteta, kuriame labiau ryškẻja funkcinè kompetencija, apimanti igūdžius ir technines žinias. Rečiau būsimujų specialistų profesiniame identitete pastebima asmenybinè kompetencija, kuri akcentuoja žinojimą kaip elgtis tam tikroje situacijoje ir kaip komunikuoti, bei etinè kompetencija, jungianti asmenines ir etines vertybes. Tai rodo, kad rengiant pedagogus studiju programose dar egzistuoja takoskyra tarp visybinio mokinio ugdymo ir jo fizinio pajègumo tobulinimo kūno kultūros veikloje (Capel et al., 2004; Kardelienè ir kt., 2009). Profesinè socializacija mokykloje keičia gimtosios kalbos išmanymo vertę (Kardelienè ir kt., 2007). Kūno kultūros mokytojai, rečiau nei būsimieji mokytojai, pritardami teiginiams apie gimtosios kalbos vartojimo svarbą kūno kultūros veikloje, dažniau nei studijuojantieji konsultuojasi su kalbininkais ir kitais specialistais, labiau gilinasi i specialiuosius leidinius apie gimtaja kalbą, jos vartojimą.

Norètųsi išsakytąsias interpretacijas pagrịsti panašiais kitų tyrèjų duomenimis. Pavyzdžiui, 
O. В. Zavjalova (Завьялова, 2002) aprašo eksperimenta, kurio metu tobulintas dziudo imtynių specialistų kalbejjimas. Eksperimento pradžioje nustatyta, kad būsimieji kūno kultūros ir sporto specialistai nèra raštingi, nes pirmame kurse, rašydami diktanta. jie padare vidutiniškai 18 klaidų, penktame - 9 klaidas ( $\mathrm{p}<0,001)$. Manoma, kad klaidų sumažèjo dèl studijuojamos literatūros, o ne dèl tikslingo kalbos tobulinimo. Tyreja analizavo ne tik studentu, bet ir jų dèstytoju gimtosios (rusų) kalbos gebejjimus. Tyrimo duomenys parode, kad ir dėstytojų, ir studentų bendrinès gimtosios (rusu) kalbos išmanymą būtina gilinti. Autorè rašo, kad eksperimentas studentu populiacijoje per dvejus metus pagerino studentu gimtosios kalbos lingvistini gebejjimą. Svarbiausia, kad būsimujų kūno kultūros ir sporto specialistu gimtosios kalbos kompetencija apskritai tapo gilesnè nei jų dèstytojų.

Verta iškelti dar viena atlikto tyrimo rezultata, kuris rodo, kad komunikavimo kompetencijos lingvistinis komponentas labiau vertinamas konvencinio bendravimo šalininkų, t. y. tokių specialistų, kurie įžvelgia galimybę susitarti bet kurioje bendradarbiavimo situacijoje, lyginant jų atsakymus su asmenimis, užimančiais hierarchinę ar manipuliacinę komunikavimo poziciją (Kardelienè ir kt., 2007). Vadinasi, geresnès gimtosios kalbos žinios, gilesni mokejjimai, igūdžiai prognozuoja veiksmingiau dirbantį mokytoją. Tokią prielaidą formuluoti leidžia ir tyrimų išvados apie kūno kultūros mokytojų rengimą, nes kūno kultūros mokytojo bendrasis išprusimas lemia ir jo pedagoginès veiklos kokybę (Chen,
2003; Grechus et al., 2007), nors jau pastebima lietuviu ir anglu kalbos konkurencija ir profesinèje veikloje, ir asmeninio gyvenimo srityje.

Tyrimo duomenų interpretacija baigtina J. Šukio (2001) pastebèjimu: būtina kalbèti apie komunikacinę kalbos kultūrą — kalbos estetiką ir kalbos etiką. Tai reikštų, kad rengiant būsimuosius pedagogus akademinè bendruomené turètu rūpintis studentu kalbos taisyklingumu ir plètote tokiu gebejjimų kaip gražiai, kultūringai bendrauti, patraukti, sudominti, daryti poveiki pašnekovui, ypač ugdytiniui.

\section{IŠVADOS}

Tokios būsimujų kūno kultūros mokytojų profesinès socializacijos apraiškos kaip gimtosios kalbos gebejjimų vertinimo tyrimas atskleidè, kad ugdant mokinių kūno kultūrą vadovaujamasi stereotipiniu požiūriu — vaikų kalbos ugdymu privalo dažniau rūpintis kitų specialybiu mokytojai.

Tyrimo prielaida pasitvirtino, nes akademinejje bendruomenèje taip pakinta būsimuju kūno kultūros mokytojų pedagoginès komunikacijos verbalinès nuostatos teiginiu iverčiai, kad IV kurso studentų vertinimai juos labiau apibūdina kaip pragmatiškus mokytojus, kurie dažnai gimtają kalbą suvokia kaip instrumentinę vertybę.

Būsimuju pedagogu gimtosios (lietuvių) kalbos vertinimas ugdant mokinių kūno kultūrą gali būti ivardytas kaip kintamasis, leidžiantis gilintis i jų profesionalumą, ypač i profesinès veiklos veiksmingumą.

\section{LITERATŪRA}

Capel, S., Whitehead, M., Zwozdiak-Myers, P. (2004). Developing and maintaining an effective learning environment. In S. Capel (Ed.), Learning to Teach Physical Education in the Secondary School: A Companion To School Experience (pp. 102-120). New York: RoutledgeFalmer.

Chen, W. (2003). Evalution of pre-service teacher preparation for achieving the national standarts for beginning physical education teachers. Journal of Personnel Evaluation in Education, 17, 331-347.

Curtner-Smith, M. D (2001). The occupational socialization of a first-year physical education teacher with a teaching orientation. Sport, Education and Society, 6 (1), $81-105$.

Fominienè, V. (2007). Kūno kultūros mokytoju nuostatos dèl pedagoginès komunikacijos kaip mokiniu požiūrio $\dot{k}$ kūno kultūros ugdymąsi determinantès: daktaro disertacija (rankraštis). Kaunas: LKKA.

Girčienė, J. (2005). Naujuju skoliniu atitikmenys: struktūra ir vartosena. Vilnius: Lietuviu kalbos institutas.

Grechus, M., Docheff D. M., Conn J. H. (2007). Physical educators assigned to teach health: T. I. P. S. Journal of Health, Physical Education, Recreation and Dance, 17, $40-47$.
Hardman, K. (2008). Physical education in schools: A global perspective. Kinesiology, 40, 1, 5-28.

Kardelienè, L., Gudzinevičiūtè, O. L., Mykolaitienė, L. (2005). Competence of Would-be specialist of physical education and sports: Urgent problems of studying language for special purpose. Ugdymas. Kūno kultūra. Sportas, 5 (59), $34-41$.

Kardelienè, L., Kardelis, K., Bagdonas, A. (2007). Būsimuju kūno kultūros mokytojų nuostatos dèl pedagoginès komunikacijos kaita. Ugdymas. Kūno kultūra. Sportas, 2 (65), 23-29.

Kardelienè, L., Kardelis, K., Karanauskienè, D., Šukys, S. (2009). Būsimuju kūno kultūros ir sporto specialistu identifikacijos: akademine, sportine ir profesine. Kaunas: LKKA.

Kardelienė, L., Kardelis, K. (2006). Pedagogine komunikacija kūno kultūros veikloje. Kaunas: LKKA.

Malinauskas, R. (2004). Sporto pedagogu socialinės parengties raida. Socialiniai mokslai, 3 (45), 27-33.

Pupkis, A. (2005). Kalbos kultūros studijos. Vilnius: Gimtasis žodis.

Ryan, S., Fleming, D., Maina, M. (2003). Attitudes of 
middle school students toward their physical education teachers and classes. Physical Educator, 60, 2, 28-42.

Šukys, J. (2001). Lietuviu kalba. Kalbos kultūra. Kaunas: Šviesa.

Teaching and Learning: Towards the Learning Society (The White Book). (1995). In I. Buchberger (2000), Struggle for diversity of language in a harmonising European context new tasks for teacher education. Paper presented at the AERA - Conference, New Orleans.

Trayner, B. (2000). The impact of global changes on the English language and the teaching of English for specific purposes. Language Teaching / Learning in the Context of Social Changes, 1, 118-123.

Unalan, D., Celikten, M., Ozturk, A., Senol, V. (2008). The relationship between vocational college students' smoking behavior and self-actualization, interpersonal support and stress management. Social Behavior and Personality, 36, $6,721-726$.
Vilkas, A., Raškauskienė, J. (2005). 5-12 klasių mergaičių požiūrio ì kūno kultūrą formavimasis ir kaita. Sporto mokslas, 3 (41), 66-71.

Župerka, K. (1997). Stilistika. Šiauliai: Šiaulių universitetas.

Завьялова, О. Б. (2002). Формирование речевого имиджа специалистов по борьбе дзюдо. Теория и практика физической культуры, 12, 20-22.

Уорд, К. (2003). Азбука аккультурации. Д. Мацумото (ред.), Психология и культура. СПб.: Питер. С. 656-696.

Чучалина, А. И., Чусовитина, О. М., Костхина Н. М. (2005). Теоретические основы профессионально-речевой подготовки будущих специалистов в области физической культуры и спорта. Теория и практика физической культуры, 10, 17-19.

\title{
PROFESSIONAL SOCIALIZATION OF WOULD-BE TEACHERS OF PHYSICAL EDUCATION: NATIVE LANGUAGE SKILLS EVALUATION IN PEDAGOGICAL COMMUNICATION
}

 \\ Lithuanian Academy of Physical Education ${ }^{1}$, Kaunas University of Medicine ${ }^{2}$, Kaunas, Lithuania
}

\begin{abstract}
The article deals with the would-be physical education teacher's mother tongue skills assessment in the pedagogical communication. The importance of the native language in would-be teachers' professionalization in higher university education was brought up in the study. While scientists go deep in to the would-be physical education teachers' professional use of language concerns, there is still lack of research on the pedagogical communication competence in the pedagogical activities, and in particular on the linguistic competence component, which rarely becomes the object of research. Linguistic component is native language skills which lead to personal knowledge, abilities and values of the native language when students' physical education is in process.

The study employed a questionnaire which allowed to reveal native language skills assessment in the process of professional socialization. The sample in the cohort-type longitudinal analysis consisted of 149 students of LAPE who were selected from the $2^{\text {nd }}(n=89)$ and the $4^{\text {th }}(n=60)$ years of studies of the Faculty of Sports Education. Interpreting the estimates of the importance of mother tongue in developing students' physical education in terms of professionalization in would-be physical education teachers should be noted that the studies of the native language are generally more regarded as instrumental and less as terminal values.

The analysis of the data suggests that native language in pedagogical communication of the would-be specialists is assessed pragmatically. The study suggert that the allow native (i.e. Lithuanian) tongue in developing students' physical education, can be assessed as a variable in their professionalism, especially regarding the efficiency and functionality of their professional activity in the professional performance and effectiveness.
\end{abstract}

Keywords: professional socialization, native language skills, pedagogical communication.

Gauta 2010 m. kovo 31 d.

Received on March 31, 2010

Priimta 2010 m. gagužès $31 \mathrm{~d}$

Accepted on May 31, 2010
Laimutė Kardelienè

Lithuanian Academy of Physical Education

(Lietuvos kūno kultūros akademija)

Sporto g. 6, LT-44221 Kaunas

Lithuania (Lietuva)

Tel +370 37302637

E-mail laimutekk@gmail.com 